\title{
The effects of shopping environment on consumption emotions, perceived values and behavioral intentions
}

\author{
Kambiz Heidarzadeh Hanzaee $^{\mathrm{a}}$ and Arezu Javanbakht ${ }^{\mathrm{b} *}$
}

${ }^{a}$ Department of Business Management, Science and Research Branch, Islamic Azad University, Qazvin, Iran ${ }^{b}$ Department of Business Management Science and Research Branch, Islamic Azad University, Qazvin, Iran

\section{H R O N I C L E}

Article history:

Received May 15, 2013

Received in revised format

25 June 2013

Accepted 7 August 2013

Available online

August 72013

Keywords:

Environment

Consumption emotions

Perceived value

Satisfaction

Behavioral intentions

Tourist

\section{A B S T R A C T}

The main objective of this study is to develop and to test a comprehensive model that investigates the effect of shopping environment on consumption emotion, perceived value and behavioral intentions in tourism setting. The proposed model specifies the effect of environment perceptions on consumption emotions (pleasure and arousal), hedonic and utilitarian value, which in turn emotions and values affect tourist's satisfaction and behavioral intentions. Data were collected through tourists who visited a tourist city by using cluster random sampling method. A total of 410 questionnaires were used for data analysis. Structural equations modeling (SEM) by using LISREL was performed to empirically test the relationships between the constructs of this research .

Results show that environment has a positive and significant influence on pleasure and arousal. However, the effect of environment perceptions on behavioral intentions was not significant. In addition, results indicate that pleasure and arousal have positive and significant effects on tourist's values. Findings also indicate that hedonic and utilitarian values had direct effect on customer satisfaction and the effect of satisfaction on behavioral intention was positive and significant. Finally, it suggests that service providers should focus on components of environment in a way that contributes positively in creating positive emotions in customers, which in turn consumption emotions enhance perceived value and positive behavioral intentions.

\section{Introduction}

The notion that atmospheric elements influence consumer behavior is widely accepted in the marketing literature, yet development of theory is clearly limited in this area (Mttila \& Wirtz, 2001). For some tourists, shopping carries a higher priority than sightseeing, diversion or any other holiday activities, so it is one of the most penetrative leisure activities that engaged in by tourists (Yuksel, 
2007). Knowing what environmental elements influence the feeling states of customers can suggest suitable marketing strategies to help develop and maintain positive shopping experiences (d'Astaus, 2000). At the same time, the role of emotions has gained much attention as a core element in recognizing service encounters and experiences, with academic research displaying that emotions experienced in a store environment can influence service outcomes, such as behavioral intentions (Lin \& Liang, 2011). In addition, in recent years, perceived value has received special attention as an important construct in anticipating consumer shopping behavior. Many researchers agree that value has a substantial impact on customer satisfaction and behavioral intentions (Ryu et al., 2010).

Researchers suggest that the key element to organizational survival is the retention of satisfied internal and external customers. They propose measuring satisfaction to manage it effectively (Trasorras et al., 2009). Satisfaction is often used as an anticipator of future consumer purchases. Satisfied customers have a higher probability of repurchasing in time (Zeithaml et al., 1996), stay more (Zeithaml et al., 1996), pay more (Zeithaml et al., 1996; Barsky \&Nash, 2002) and of becoming less receptive to the competitor's offerings (Moraga et al., 2008).

In spite of significant tourist shopping and tourist behavior, research on tourist shopping behavior is surprisingly limited. In fact, relationship between tourist's perceptions of environmental, their emotional responses, perceived value and behavioral intentions have not been well documented. By addressing this research shortage, the present study attempts to propose and empirically test a more comprehensive model of tourist's shopping environment, which consists of external environment, hedonic and utilitarian value, consumption emotions, customer satisfaction and tourist's behavioral intentions. In fact, the proposed model specifies the effect of environment perceptions on consumption emotions (pleasure and arousal), hedonic and utilitarian value, which in turn emotions and values affect tourist's satisfaction and behavioral intentions.

This study is organized as follows: First we review the literature on shopping environment at a tourist destination, shopping emotion, shopping value, satisfaction and behavioral intentions and develop a conceptual model. Next, we present the results of testing the model using SEM analysis, discuss the findings and outline some theoretical and managerial implications of our analysis. Finally, we discuss the limitations of study and offer suggestions for future research.

\section{Conceptual Framework and Hypotheses}

\subsection{Environment}

Service environments play an important role in service delivery because environments can bring up pleasant emotional responses, while strengthening customer perceptions and retention (Lin \& Liang, 2011). However, there is a question on what do we mean by the shopping environment? To define the environment, a common approach is to distinguish the person ("me") from the physical features that surround him or her ("not me"). The features that comprise consumers' environments are too numerous so, Listing all them is an impossible task (d'Astous, 2000). According to Kotler (1973) the physical environment in which a product is purchased is an important part of the total consumption package (Countryman \& Jang, 2006).

Environmental psychologists argue that a critical role of the physical environment is its ability to facilitate or hinder the goals of people within that environment (Grewal et al., 2003). Though Kotler's classification has not been used as a general framework for theory construction, it has stimulated and oriented research on the impact of environmental factors on consumer behavior (Donovan et al., 1994). However Bitner's (1992) servicescape, focusing on the physical aspects of the environment, including ambient and design factors has been the most widely cited typology, but for many service firms, the effect of other individuals is also critical (Lin \& Liang, 2011). Some people recommend that ambient elements such as lighting, music, etc. and social elements are essential atmospheric 
factors, which influence consumers' affective states in the shopping environment, which in turn, impact their feature purchasing behavior (Michon et al., 2008).

Berman and Evans (1995) categorized these environmental factors into two groups of external and general interior variables (Yuksel, 2007). The external variables incorporate the storefront, marquee, entrances, display windows, building architecture, the surrounding area, and parking. However, a number of studies have investigated the impacts of various external variables of a shopping environment is substantially limited. This part of the environment needs more attention because the exterior is the first set of cues normally observed by a consumer. If these variables are not managed well, the rest of the atmosphere may not be important (Turley \& Milliman, 2000).

Grossbart et al. (1975) illustrated that external characteristics of a shopping district had an impact on the behavior of retail customers. Other researchers investigating the links between evaluations of the store environment as a whole and purchase behaviors reported similar strong relationships (Yuksel, 2007). Many marketing scholars investigating retail atmospherics followed Mehrabian and Russell's pleasure/arousal research tradition in which mood is a mediating factor between environmental cues and behavior (Chebat \& Michon 2003). This model consists of three parts: environmental stimuli, emotional states, and approach or avoidance responses. The environment creates an emotional response in individuals which, in turn, elicits either approach or avoidance behavior (Ryu \& jang, 2008). Based on these arguments, we test the following hypotheses:

$\mathrm{H}_{1}$ : Environmental perception is positively associated with behavioral intentions.

$\mathrm{H}_{2}$ : Environmental perception is positively associated with pleasure.

$\mathrm{H}_{3}$ : Environmental perception is positively associated with arousal.

\subsection{Consumption Emotions}

Customer emotion has been considered as a primary element in understanding perceptions of service experiences. Since it forms an essential source of human motivation and exerts substantial impact on the thought processes (Lin \& Liang, 2011), many people have attempted to define and examine emotion. Gardner (1985) defined emotion as feelings associated with a specific behavior (Han \& Back, 2007). Plutchik used an evolutionary perspective to detect eight "primary" emotions consisting of fear, anger, sadness, joy, disgust, acceptance, surprise, and expectancy (Richins, 1997). According to Roos and Friman, (2008) Emotions include three components:

(1) A strong impulse to act;

(2) A pattern of bodily change; and

(3) A subjective evaluation commonly referred to as affect.

There seems to be no practical solution to the debate on which component is enough or necessary to define emotion (Martin et al., 2008). However, most marketing scholars investigating retail environments implemented Mehrabian and Russell's pleasure/arousal research tradition in which mood is a mediating factor between environmental cues and behavior (Chebat \& Michon, 2003).

Mehrabian and Russell (1974) posited that any environment, including that of a tourist shopping environment could yield three emotional states in an individual including pleasure, arousal, and dominance (Yuksel, 2007). Dominance, however, has been shown to have a non-significant impact on behavior (Jang \& Namkung, 2009). Pleasure-displeasure is associated to the degree in which the person feels good, joyful, happy, or satisfied in the situation. Arousal-nonarousal is associated with the degree in which a person feels excited, stimulated, alert or active in the situation (Bigne et al., 
2006). The role of the PA model in consumer behavior is noteworthy. Many studies have shown that pleasure and arousal influence attitudes and a variety of responses such as utilitarian and hedonic values (Yuksel, 2007), spending level, desire to affiliate, spent in the store (Donovan \& Rossiter, 1982), liking the store, number of items purchased in the store, willingness to patronize the store, and willingness to buy (Ladhari, 2007). Obermiller and Bitner (1984) explained that respondents who viewed retail products in an emotionally pleasing environment evaluated products more positively than subjects who considered the same goods in an unpleasant environment. Results of the study disclosed that the effect of perceived crowding on shopping value was mediated by emotions experienced by the shopper (Ryu et al., 2010). In addition, pleasure and arousal directly affect shoppers' behavioral intentions and indirectly influence through hedonic and utilitarian shopping values (Yuksel, 2007). This arguments leads to our next research hypotheses:

$\mathrm{H}_{4}$ : Pleasure is positively associated with hedonic shopping value.

$\mathrm{H}_{5}$ : Pleasure is positively associated with utilitarian shopping value.

$\mathrm{H}_{6}$ : Arousal is positively associated with hedonic shopping value.

$\mathrm{H}_{7}$ : Arousal is positively associated with hedonic shopping value.

$\mathrm{H}_{8}$ : Pleasure is positively associated with behavioral intentions.

$\mathrm{H}_{9}$ : Arousal is positively associated with behavioral intentions.

\subsection{Shopping value}

Since creating perceived value for customers is considered as a key success factor for professional service business units, it has gained traction in various streams of marketing literature in recent years (Trasorras et al., 2009). Shopping value includes an interaction between a consumer and a product or service that pertains not only to the object itself, but also to the consumption experience. It includes both the intrinsic and extrinsic value of the object (Michon et al., 2008). The growing body of conceptual knowledge about perceived value is quite fragmented, but there is no widely acceptance for implementing them to service settings (Chen $\& \mathrm{Hu}, 2009$ ), also in tourism research, a number of studies have adopted the customer perceived value perspective and some literature reviews are available (Saraniemi, 2010). The recognition of the relevance of value in tourism markets is normally based on the utility of value as a strategic tool for the management of tourism services. Its importance is also considered as a key variable for analyzing consumer behavior (Gallarza \&Gil, 2008).

The measurement of customer value can be categorized as unidimensional or multi-dimensional (Cataluna \& Ruiz, 2010). Previous studies investigated perceived value in terms of monetary tradeoffs only - what we get for what we pay (kumar \& Lim, 2008). However, other researchers have criticized that shopping value should consider more than simply functional utility, so consumer value classifications must be represented as the dichotomization of utilitarian and hedonic values (Ryu et al., 2010). Utilitarian consumer value can be explained as a rational approach involving a purchase that is efficiently made, even if the shopping itself may not provide any fun (Cardoso \& Pinto, 2010). Hedonic consumption designates those facets of consumer value that are associated with the multisensory, fantasy and emotive aspects of one's experience with products (Rintamaki et al., 2006).

The range of products purchased by tourists is different and it does not just consist of souvenirs and necessary personal items. Hence, they are anticipated to look for varying degrees of both utilitarian and hedonic profits from a shopping (Yuksel, 2007). Recent studies have explored the hedonic and utilitarian perspective, concentrating on the factors, which influence entertaining shopping experiences and examining perceived value in specialty shops environments, in the context of second-hand shops and relating crowding with retail satisfaction (Cardoso \& Pinto, 2010). Various 
researchers have verified the substantial relationship among value, customer satisfaction and behavioral intention in business and hospitality fields. Indeed, Ryu et al. (2010); Babin et al. (1994) disclosed that both the hedonic and utilitarian value impact customer satisfaction. The emotions and shopping value reactions, mediate the impact of spatial crowding on shopping satisfaction. Consumers are more likely to return and spend more with a retailer who provides relatively high utilitarian or hedonic shopping value (Yuksel, 2007).

$\mathrm{H}_{10}$ : Hedonic shopping value is positively associated with behavioral intentions.

$\mathrm{H}_{11}$ : Utilitarian shopping value is positively associated with behavior intentions.

$\mathrm{H}_{12}$ : Hedonic shopping value is positively associated with satisfaction.

$\mathrm{H}_{13}$ : Utilitarian shopping value is positively associated with satisfaction.

\subsection{Customer satisfaction}

Customer satisfaction with a company's goods or services is often considered as the key component to a company's success and long-term competitiveness (Law et al., 2004). During the last four decades, satisfaction has been considered as one of the most important theoretical as well as practical issues for many marketers and customer researchers (Martın-Consuegra et al., 2007). Traditionally satisfaction was considered to be a cognitive state, affected by cognitive antecedents, and recently, the need to perceive satisfaction from a more affective perspective in connection with cognitive effects has been highlighted (Bigne et al., 2005). Consumer satisfaction is described as a whole evaluation or a state of feelings associated with a product or service (Espejel et al., 2008). Disconfirmation model posited that satisfaction is defined as the difference between what a consumer expects to receive and his/her perceptions of actual delivery (Martin et al., 2008).

If performance is equal to customer expectations, consumers experience confirmation of their expectations; if performance is well above their expectations, consumers experience positive disconfirmation; and if performance is less than their expectations, consumers experience negative disconfirmation (Phillips \& Baumgartner 2002). Understanding what affects consumer satisfaction can help business owners and managers design suitable offers that cater to market demand (Hanzaee et al., 2012).

A number of satisfaction studies have been considered in the tourism sector. Most have concentrated on computing the quality of tourists' experiences and how different quality performance factors influence on tourists' satisfaction (Williams \& Soutar 2009). Kandampully and Suhartanto's (2000) reported that customer satisfaction and hotel image with the service performance were positively associated with customer intentions to recommend (Han \& Back, 2007; Lin \& Liang, 2011). In addition, the literature demonstrates conflicting evidence regarding the effect of satisfaction levels on behavioral intentions such as the extent of positive word of mouth activities (Ladhari, 2007; Oliver, 1997), repurchase (Lin \& Liang, 2011; Han \& Back, 2007), purchase volume (Lin \& Liang, 2011), and loyalty (Lin \& Liang, 2011; Oliver, 1997).

$\mathrm{H}_{14}$ : customer satisfaction is positively related to behavioral intentions.

\section{Research model}

Based on preceding literature, the hypothesized relationships are shown in the conceptual framework in Fig. 1, which investigates the effects of environment on emotion, satisfaction and perceived value. 


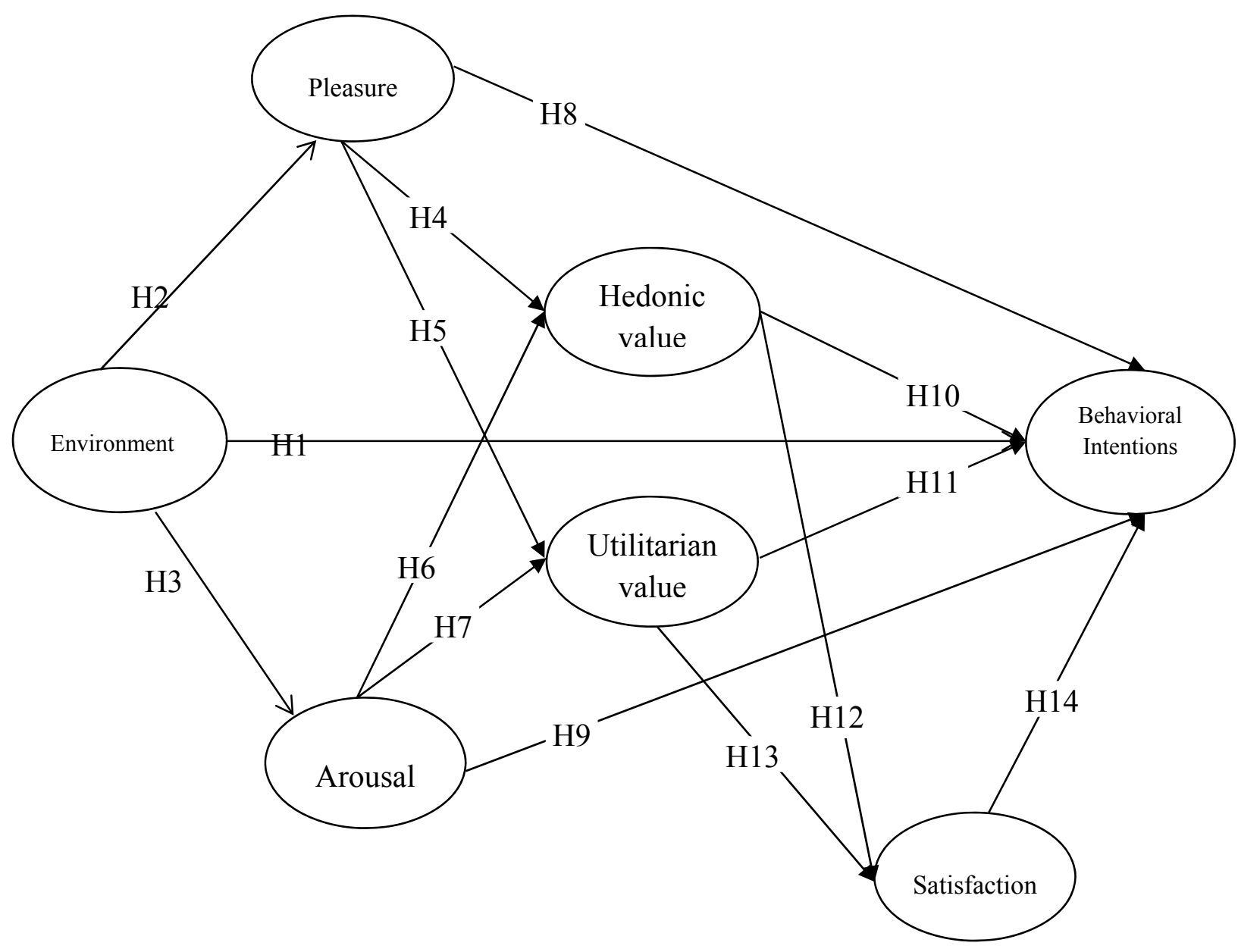

Fig. 1. Research conceptual model

\section{Measurement items, Sample population and Data Collection Procedure}

Self-administrated questionnaire was applied for entire survey. In this study, questionnaire includes two parts, i.e. demographic questions and questions associated with knowing the effects of the environment on emotions, perceived value, satisfaction and behavioral intention. In order to examine the hypotheses empirically, multi-item scales validated in previous studies were modified and adopted for this study. The constructs were measured by means of 5-point Likert scale and semantic differential scale. The sources for each construct and their items implemented in the questionnaire of this study are as follows:

The perceptions of the environment of the retail district were measured by six items adapted from Mattila \& Wirtz (2001) and Yuksel (2007). A five-point semantic differential adjective pairs operationalized environmental perception. Consumption emotion was measured by using eight items adapted from Ruiz et al. (2004) and Yuksel (2007), representing the pleasure and arousal dimensions. Personal shopping value was assessed by eight items taken from Babin et al. (2004) and Yuksel (2007). To measure the satisfaction, we used five items five-point Likert adapted and modified from Oliver (1980) and Ladhari (2007). Behavior intention was measured by using the five-item five-point Likert adapted from Cronin et al. (2000) and Lin \& Liang (2011). 
A tourist city selected as the research setting to test the conceptual model and research hypotheses outlined in Figure 1. Data were collected from tourists that visiting and shopping from spas and hotels in Sarein city in Iran. Cluster random sampling was used; data were collected from 460 shoppers of spas and hotels at the tourist city. A total of 410 usable questionnaires were retained. The demographic characteristics of the sample were shown in Fig. 2.

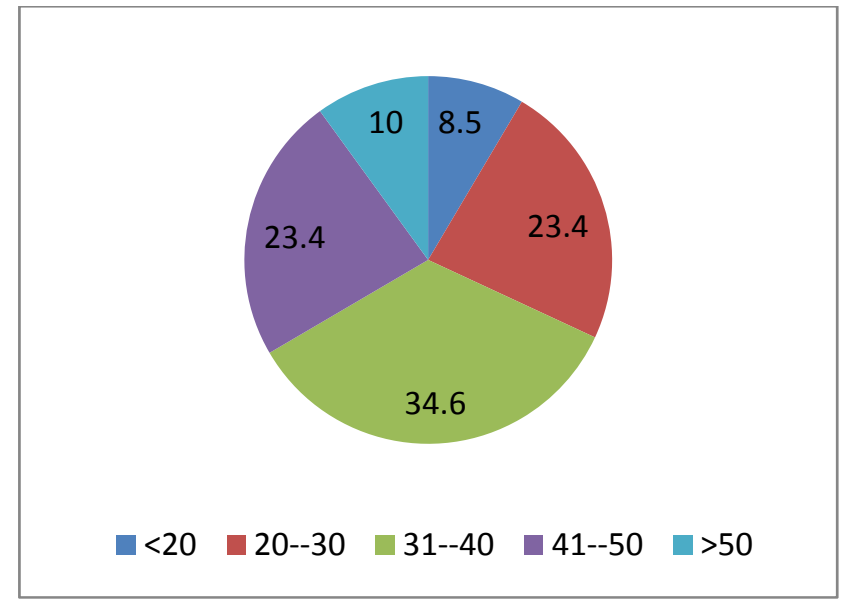

Age

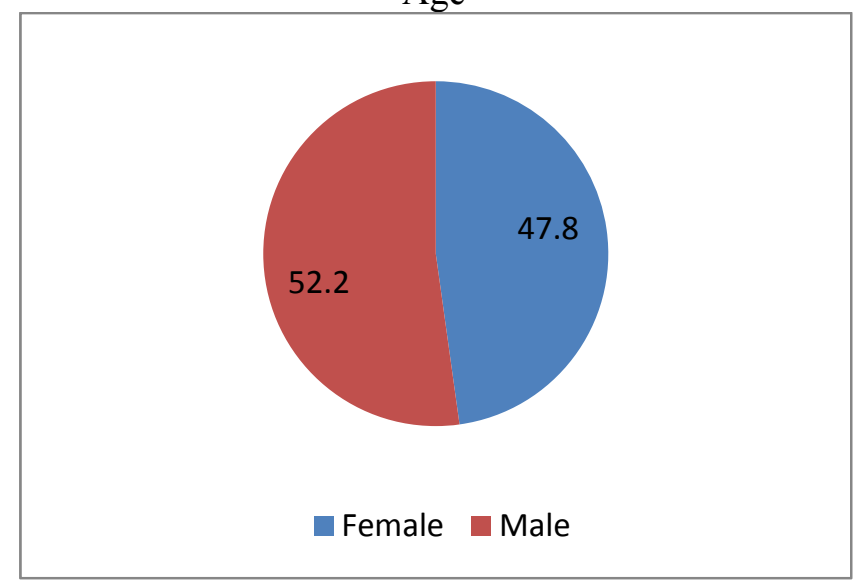

Gender

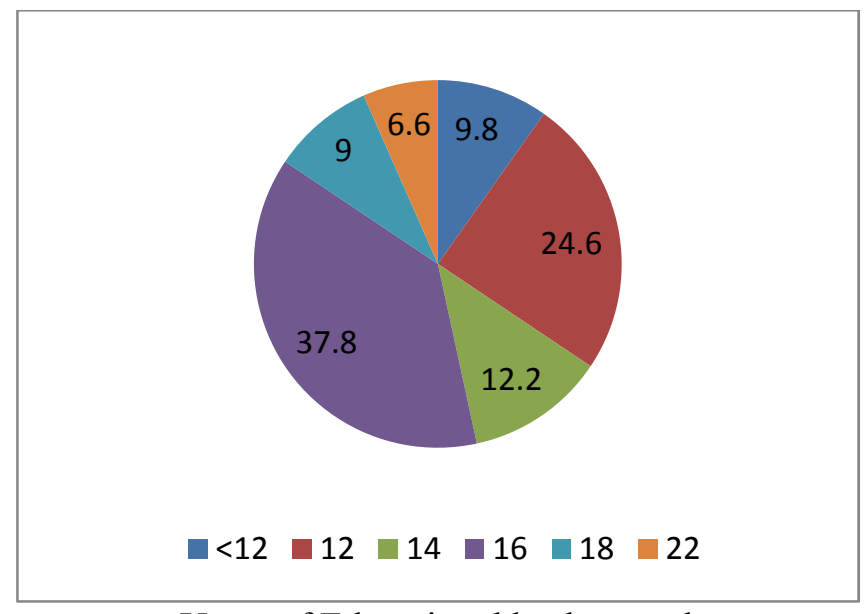

Years of Educational background

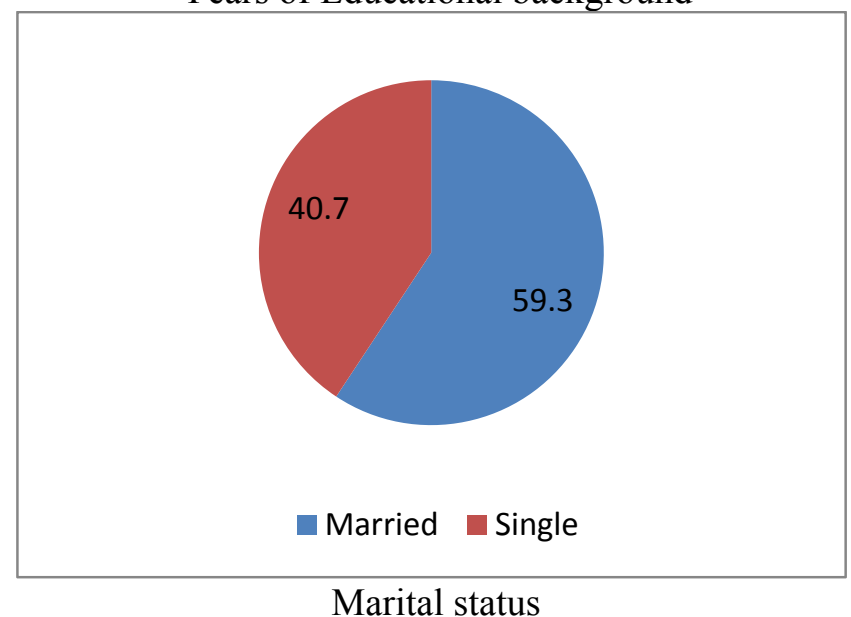

Fig. 2. Personal characteristics of participants (\%)

\section{Analysis and Results}

Structural Equations Modeling (SEM) by using LISREL for Windows was applied to examine the relationships between constructs in this study. In this model, as suggested by Anderson and Gerbing (1988), data were analyzed by using the two-step approach in which the measurement model was first confirmed and then the structural model was tested.

\subsection{Measurement model estimation}

Confirmatory factor analysis (CFA) was directed to examine the factor structure of the measurement model in this paper (Anderson \& Gerbing, 1988). Table 1 presents the factor loadings and Cronbach's alphas of the items on the latent constructs as estimated by the CFA. Cronbach's alphas of latent constructs were acceptable for all ten constructs $(0.70-0.87)$. Values were all above 0.70 as suggested by Nunnally (1978), and therefore indicated internal consistent. 


\section{Table 1}

Confirmatory factor analysis results

\begin{tabular}{|c|c|c|c|}
\hline Constructs & Standardized loadings & t- value & Cranach's $\alpha$ \\
\hline Environment & & & 0.87 \\
\hline EN 1 & 0.74 & - & \\
\hline EN 2 & 0.70 & 15.06 & \\
\hline EN 3 & 0.75 & 16.79 & \\
\hline EN 4 & 0.73 & 10.51 & \\
\hline EN 5 & 0.70 & 15.12 & \\
\hline EN 6 & 0.54 & 11.05 & \\
\hline Pleasure & & & 0.81 \\
\hline PLE 1 & 0.78 & - & \\
\hline PLE 2 & 0.79 & 16.36 & \\
\hline PLE 3 & 0.79 & 16.45 & \\
\hline PLE 4 & 0.76 & 15.63 & \\
\hline Arousal & & & 0.70 \\
\hline ARO 1 & 0.60 & - & \\
\hline ARO 2 & 0.68 & 10.76 & \\
\hline ARO 3 & 0.79 & 11.84 & \\
\hline ARO 4 & 0.72 & 11.16 & \\
\hline Hedonic & & & 0.81 \\
\hline HVA 1 & 0.80 & - & \\
\hline HVA 2 & 0.83 & 18.72 & \\
\hline HVA 3 & 0.82 & 18.30 & \\
\hline HVA 4 & 0.72 & 15.66 & \\
\hline HVA 5 & 0.78 & 17.29 & \\
\hline Utilitarian & & & 0.82 \\
\hline UVA 1 & 0.80 & - & \\
\hline UVA 2 & 0.78 & 15.50 & \\
\hline UVA 3 & 0.73 & 14.50 & \\
\hline Satisfaction & & & 0.83 \\
\hline SAT 1 & 0.72 & - & \\
\hline SAT 2 & 0.72 & 13.84 & \\
\hline SAT 3 & 0.76 & 14.59 & \\
\hline SAT 4 & 0.71 & 13.59 & \\
\hline SAT 5 & 0.63 & 11.98 & \\
\hline Behavioral Intentions & & & 0.78 \\
\hline BI 1 & 0.70 & - & \\
\hline BI 2 & 0.78 & 15.04 & \\
\hline BI 3 & 0.76 & 14.80 & \\
\hline BI 4 & 0.76 & 14.66 & \\
\hline
\end{tabular}

The overall evaluation of the model fit was based on multiple indicators. These indicators included the $\chi 2$; the normed fit index (NFI), the nonnormed fit index (NNFI), the comparative fit index (CFI), the root mean squared error of approximation (RMSEA), the Goodness of Fit Index (GFI) and Adjusted Goodness of Fit Index (AGFI). The fit statistics showed that the measurement model fit the data reasonably well.

\subsection{Structural Model}

After assessing and confirming the total measurement model, the structural model was estimated; Results indicated an acceptable level of fit between the hypothesized model and the data. $(\chi 2=923$, df $=388, \mathrm{GFI}=0.92, \mathrm{AGFI}=0.90, \mathrm{NFI}=0.97, \mathrm{NNFI}=0.98, \mathrm{CFI}=0.98 \mathrm{IFI}=0.98, \mathrm{RFI}=0.97$ and RMSEA $=0.058)$. Results show that environment has a positive and significant influence on pleasure (path coefficient $=0.79, \mathrm{t}=13.83$ ) and arousal (path coefficient $=0.82, \mathrm{t}=10.99$ ). However, hypothesized effect of environment perceptions on behavioral intentions was not significant (path coefficient $=0.10$, $\mathrm{t}=1.03$ ). In addition, results indicate that pleasure has a positive and significant effect on tourist's hedonic (path coefficient $=0.38, \mathrm{t}=5.84$ ) and utilitarian (path coefficient $=0.48, \mathrm{t}=6.20$ ) values. As 
predicted arousal have a positive and significant effect on hedonic (path coefficient $=0.46, \mathrm{t}=6.23$ ) and utilitarian (path coefficient $=0.45, \mathrm{t}=4.03$ ) values. However, hypothesized effect of pleasure (path coefficient $=0.07, t=1.00$ ) and arousal (path coefficient $=0.06, t=0.79$ ) on behavioral intentions is not supported. Findings revealed that Hedonic (path coefficient $=0.51, \mathrm{t}=8.95$ ) and utilitarian (path coefficient $=0.45, t=7.91$ ) values had direct effect on customer satisfaction. In addition, hedonic value has a direct effect on customer behavioral intentions (path coefficient $=0.44, \mathrm{t}=6.38$ ). However, utilitarian value had not direct effect on customer behavioral intentions (path coefficient $=0.11$, $\mathrm{t}=1.79$ ). Also, effect of satisfaction on behavioral intention (path coefficient $=0.62, \mathrm{t}=7.45$ ) was positive and significant.

Table 2

Path estimates and hypotheses results for proposed model

\begin{tabular}{|c|c|c|c|c|}
\hline Hypotheses & & Path confident & T-value & results \\
\hline H1: EN & $\mathrm{BI}$ & 0.10 & 1.03 & Not supported \\
\hline H2: EN & PLE & 0.79 & 13.83 & Supported \\
\hline $\mathrm{H} 3: \mathrm{EN}$ & ARO & 0.82 & 10.99 & Supported \\
\hline H4: PLE & HVAL & 0.38 & 5.84 & Supported \\
\hline H5: PLE & UVAL & 0.48 & 6.20 & Supported \\
\hline H6: ARO & HVAL & 0.46 & 6.23 & Supported \\
\hline H7: ARO & UVAL & 0.45 & 4.03 & Supported \\
\hline H8: PLE & $\mathrm{BI}$ & 0.07 & 1.00 & Not supported \\
\hline H9: ARO & BI & 0.06 & 0.79 & Not supported \\
\hline H10: HVAL & $\mathrm{BI}$ & 0.44 & 6.38 & Supported \\
\hline H11: UVAL & BI & 0.11 & 1.79 & Not supported \\
\hline H12: HVAL & SAT & 0.51 & 8.95 & Supported \\
\hline H13: UVAL & SAT & 0.45 & 7.91 & Supported \\
\hline H14: SAT & $\mathrm{BI}$ & 0.62 & 7.45 & Supported \\
\hline
\end{tabular}

\section{Discussion and conclusion}

The Main objective of this study was to investigate the effects of environment perceptions on emotions, perceived value and behavioral intentions in tourist setting. In fact, this research proposes exterior environmental perception associated with shopping location as an important construct shaping tourists behavioral intentions.

The research findings revealed that shopping environment has a positive effect on customer pleasure and arousal and the result are consistent with previous studies. Past studies found that when environmental cues are pleasing and attractive, customers experience more positive emotions in setting (Lin \& Liang, 2011; Ryu \& Jang, 2008; Yuksel, 2007). Therefore, Managers need to recognize the profits derived from paying special attention to service external environment in differentiating themselves from competitors. These macro environmental elements lie largely within the area of management control and can be manipulated to influence customer emotions, perceptions, and behaviors. Managers can easily change environmental elements such as storefront, entrances, display windows, building architecture, and the surrounding area, based on the customer preferences to help them feel pleased, excited, or relaxed. However, impact of environment perceptions on behavioral intentions was not significant. In addition, results indicate that pleasure and arousal have a positive and significant effect on tourist's hedonic and utilitarian values. These results supported findings of Babin et al. (2005) and Yuksel, (2007), and implies that environmental cues improves affect, which in turn helps create greater hedonic value and more approach behaviors. Also, these results implies that retailers not only should induce fun and entertaining shopping experiences, 
because tourists may not want entertaining shopping experiences on every shopping occasion, so, environment should make the shopper comfortable yet excited. In addition, the hypothesized effect of pleasure and arousal on behavioral intentions is not supported. Findings revealed that Hedonic and utilitarian values had direct effect on customer satisfaction, this result is consistent with the findings of Babin et al, (2005); Wu \& Liang, (2009) and Ryu et al. (2010). Measures of the hedonic and utilitarian shopping values enable marketers to examine the effectiveness of their marketing efforts that stress experiential or functional positioning strategies. The present study highlights that if customers feel that they have received higher hedonic and utilitarian value, they will be more likely to be satisfied with their experience.

In addition, findings disclosed that hedonic value had a direct effect on customer behavioral intentions, these results supported findings of Babin et al. (2005); Yuksel, (2007) and Ryu et al. (2010). This result implies that the hedonic aspect of value should not be ignored. In other words, enjoyment is a substantial predictor of consumer service value in the tourism industry. This may involve or need the implementation of a more entertaining environment that makes them enjoyable or exciting to experience. However, utilitarian value did not have direct impact on customer behavioral intentions. Results found that effect of satisfaction on behavioral intention was positive and significant, this result is consistent with the findings of Babin et al. (2005); Wu \& Liang, (2009); Ryu et al. (2010) and Lin and Liang (2011). There is a strong consensus in the tourism industry that positive word of mouth recommendations and repeat purchase are important stimulants for future business. These findings indicate that managers should enhance costumers satisfaction to determine the extent in which customers intended to positive word of mouth, repurchase and willing to pay more. Overall, the results of this paper suggests that service providers should focus on components of environment in a way that contributes in positively creating positive emotions in customers, which in turn consumption emotions enhance perceived value and positive behavioral intentions.

This research has some limitations that research findings must be considered within the limitations of the research methodology. It has not taken into effects of demographics and cultural norms on emotional and behavioral responses of customers. Thus, the effects of demographics and cultural norms on environmental perceptions should be investigated in the future. Data were obtained from hotels and spas customers in tourist city, so the limitation in generalizability of the results is not deniable. Additional research is needed to examine these relationships within and across additional sectors. Finally, in construct of behavior intention we investigate approach behaviors, Additional research is needed to entering avoidance behaviors in study.

\section{References}

Babin, B.J., Lee, Y.K., Kim E.J., \& Griffin, M. (2005). Modeling consumer satisfaction and word-ofmouth: restaurant patronage in Korea. Journal of Services Marketing, 19(3),133-39.

Barsky, J., \& Nash, L. (2002). Evoking emotion: affective keys to hotel loyalty. Cornell Hotel and Restaurant Administration Quarterly, 4, 39-46.

Bigne, J.E., Andreu, L., \& Gnoth, J. (2005). The Theme Park Experience: An Analysis of Pleasure, Arousal and Satisfaction. Tourism Management, 26, 833-844.

Bitner, M.J. (1992). Servicescapes: the impact of physical surroundings on customers and employees. Journal of Marketing, 56(2), 57-71.

Campo, S., \& Yague, M.J. (2009). Exploring non-linear effects of determinants on tourists' satisfaction. International Journal of Culture, Tourism and Hospitality Research, 3, 127-138.

Cardoso, P.R., \& Pinto, S.C. (2010). Hedonic and utilitarian shopping motivations among Portuguese young adult consumers. International Journal of Retail \& Distribution Management, 38, 538-558.

Cataluna, F.J.R., \& Ruiz, D.M. (2010). Customers' perceptions about concerts and CDs. Management Decision, 48, 1410-1421. 
Chebat, J.C., \& Michon, R. (2003). Impact of ambient odors on mall shoppers' emotions, cognition, and spending: a test of competitive causal theories. Journal of Business Research, 56, 529-39.

Chen, P.T., \& Hu, H.H. (2010). How determinant attributes of service quality influence customerperceived value An empirical investigation of the Australian coffee outlet industry. International Journal of Contemporary Hospitality Management, 22, 535-551.

Consuegra, D.M., Molina, A., \& Esteban, A. (2007). An integrated model of price, satisfaction and loyaty: an empirical analysis in the service sector. Journal of Product \& Brand Management, 16, 459-68.

Countryman, C.C. \& Jang, S. (2006), The effects of atmospheric elements on customer impression: the case of hotel lobbies. International Journal of Contemporary Hospitality Management. 18, 534-45.

Cronin, J.J., Brady, M.K \& Hult, G.T.M. (2000). Assessing the effects of quality, value, and customer satisfaction on consumer behavioral intentions in service environments. Journal of Retailing, 76(2), 193-217.

d'Astous, A. (2000). Irritating aspects of the shopping environment. Journal of Business Research. 49(2), 149-156.

Donovan, R.J and Rossiter, J.R. (1982). Store atmosphere: an environmental psychology approach. Journal of Retailing. 58(1), 34-57.

Donovan, R.J., Rossiter, J.R., Marcoolyn, G. and Nesdale, A. (1994). Store atmosphere and purchase behavior. Journal of Retailing. 70(3), 283-294.

Espejel, J., Fandos, C., \& Flavia'n, C. (2008). Consumer Satisfaction: A Key Factor of Consumer Loyalty and Buying Intention of a PDO Food Product. British Food Journal, 110, 865-881.

Grewal, D., Baker, J., Levy, M. \& Voss, G.B. (2003), The effects of wait expectations and store atmosphere evaluations on patronage intentions in service-intensive retail stores. Journal of Retailing. 79, 259-68.

Han, H., \& Back, K.J. (2007). Investigating the Effects of Consumption Emotions on Customer satisfaction and repeat visit Intentions in the lodging Industry. Journal of Hospitality Marketing \& Management. 15, 5-30.

Hnzaee, K.H., Bigdeli, F., Khanzadeh, M \& Javanbakht, A. (2012). Assessing Patients Behavioral Intentions through Service Quality and Perceived Value. Journal of Basic Applied Science Research, 2(10), 10686-10692.

Jang, S and Namkung, Y. (2009). Perceived quality, emotions, and behavioral intentions: application of an extended Mehrabian-Russell model to restaurants. Journal of Business Research, 62(4), 451-460.

Kumar, A., \& Lim, L. (2008). Age differences in mobile service perceptions: comparison of Generation Y and baby boomers. Journal of Services Marketing, 22(7), 568-577

Ladhari, L. (2007). The effect of consumption emotion on satisfaction and word of mouth communication. Psychology \& Marketing, 12, 1085-1108.

Law, A.K.Y., \& Zhao, Y.V.H.X. (2004). Modeling repurchase frequency and customer satisfaction for fast food outlets. International Journal of Quality \& Reliability Management, 21, 545-563.

Lin, J.S.C., \& Liang, H.Y. (2011). The Influence of Service Invironments on Customer Emotion and Service Outcomes. Managing Service Quality, 21, 350-372.

Martin, D., O'Neill, M., Hubbard, S., \& Palmer, A. (2008). The role of emotion in explaining consumer satisfaction and future behavioral intention. Journal of Services Marketing, 3, 224-36.

Mattila, A.S., \& Wirtz, J. (2001). Congruency of scent and music as a driver of in-store evaluations and behavior. Journal of Retailing, 77, 273-289.

Mehrabian, A., \& Russell, J.A. (1974). An Approach to Environmental Psychology. MIT Press, Cambridge, $M A$.

Michon, R., Yu, H., Smith, D.R., \& Chebat, J.C. (2008). The influence of mall environment on female fashion shoppers' value and behavior. Journal of Fashion Marketing and Management. $12,456-468$. 
Moraga, M.E., Parraga, A.Z.V., \& Gonzalez, J.Z. (2008). Customer satisfaction and loyalty: start with the product, culminate with the brand. Journal of Consumer Marketing, 25(5), 302-313.

Nunnally J.C. (1978). Psychometric theory. McGraw-Hill, New York, NY.

Oliver, R.L. (1980). A Cognitive model of the antecedents and consequences of satisfaction decisions. Journal of Marketing Research, 17, 460-469.

Oliver, R.L. (1997). Satisfaction. A behavioral perspective on the consumer. Singapore: McGrawHill.

Phillips, D.M., \& Baumgartner, H. (2002). The role of consumption emotions in the satisfaction response. Journal of Consumer Psychology, 12(3), 243-252.

Rintamaki, T., Kanto, A., Kuusela, H., \& Spence, M.T. (2006). Decomposing the value of department store shopping into utilitarian, hedonic and social dimensions. International Journal of Retail \& Distribution Management, 34, 6-24.

Roos, I., \& Friman, M. (2008). Emotional experiences in customer relationships - a telecommunication study. International Journal of Service Industry Management. 19, 281-301.

Ryu, K., Han, H., \& Jang, S. (2010). Relationships Among Hedonic and Utilitarian Values, Satisfaction and Behavioral Intentions in the Fast-Casual Restaurant Industry. International Journal of Contemporary Hospitality Management, 22(3), 416-432.

Ryu, K., \& Jang, S. (2008). Influence of restaurants' physical environments on emotion and behavioral intention, The Service Industries Journal. 28(8), 1151-1165.

Richins, M.L. (1997). Measuring emotions in the consumption experience. Journal of Consumer Research, 24,127-46.

Saraniemi, S. (2010). Destination brand identity development and value system. Tourism Review. 65, 52-60.

Trasorras, R.,Weinstein, A., \& Abratt, R. (2009). Value, Satisfaction, Loyalty and Retention in Professional Services. Marketing Intelligence \& Planning. 27, 615-632.

Turley, L.W., \& Milliman, R.E. (2000). Atmospheric Effects on Shopping Behavior: A Review of the Experimental Evidence. Journal of Business Research, 49, 193-211.

Williams, P., \& Soutar, G.N. (2009). Value, satisfaction and behavioral intentions in an adventure tourism context, Annals of Tourism Research. 36, 413-438.

Wu, C.H.J., \& Liang, R.D. (2009), Effect of Experiential Value on Customer Satisfaction with Service Encounters in Luxury-Hotel Restaurants. International Journal of Hospitality Managementm 28, 586-93.

Yuksel, A. (2007). Tourist shopping habitat: Effects on emotions, shopping value and behaviors. Tourism Management, 28, 58-69.

Zeithaml, V.A., Berry, L.L., \& Parasuraman, A. (1996). The behavioral consequences of service quality. Journal of Marketing, 60(2), 31-46. 